\title{
Beta-casein A1/A2, kappa-casein and beta-lactoglobulin polymorphisms in Turkish cattle breeds
}

\author{
Havva Dinc', Emel Ozkan², Evren Koban ${ }^{3}$ and Inci Togan' \\ 'Department of Biological Sciences, Middle East Technical University, Ankara, Turkey, ${ }^{2}$ Department of Animal Sciences, \\ Agricultural Faculty, Namık Kemal University, Tekirdağ, Turkey, ${ }^{3}$ Genetic Engineering and Biotechnology Institute, \\ TUBITAK-MAM, Kocaeli, Turkey
}

\begin{abstract}
In this study, the genetic diversity of three milk protein genes namely beta-casein, kappacasein and beta-lactoglobulin was estimated in Turkish cattle breeds. Based on these genes, breeds in Turkey have been grouped as: 1) Eastern Anatolian Red, Anatolian Black and Southern Anatolian Red and 2) Turkish Grey, Turkish Holstein and Holstein Candidate Bulls. $B$ alleles of the three studied genes, which were reported to be positively related with cheese yield and quality, seemed to be low-intermediate for beta-casein and kappa-casein but relatively high for beta-lactoglobulin in the first group of Turkish breeds compared to other breeds of the world. The kappa-casein E allele, which has a negative effect on cheese quality, is absent in Turkish cattle breeds, except in Holstein Candidate Bulls. Therefore, the results suggest that milk of Turkish native breeds is suitable for cheese making. Based on observations of the Turkish breeds, some suggestions were made regarding breeding practices in Turkey.
\end{abstract}

Keywords: beta-casein, Kappa-casein, beta-lactoglobulin, cheese quality/yield, Turkish cattle breeds

Abbreviations: AB: Anatolian Black, BLG: beta-lactoglobulin, EAR: Eastern Anatolian Red, HCB: Holstein Candidate Bull, SAR: Southern Anatolian Red, TG: Turkish Grey, TH: Turkish Holstein 


\section{Introduction}

Bovine milk proteins are divided into two main groups; caseins (alpha ${ }_{51}$-casein, alpha ${ }_{52}$-casein, beta-casein and kappa-casein) and whey proteins that are composed of several different proteins, of which beta-lactoglobulin (BLG) is one (Eigel et al. 1984). DNA-based methods have been used to screen both sexes with respectto milkprotein polymorphismsincattle (forinstance: Daniela \& Vintila 2005, Jann et al. 2004, Rachagani et al. 2006, Strzalkowska et al. 2002). Some studies were carried out to confirm genetic relationships between different breeds (Ceriotti et al. 2004, lbeagha-Awemu \& Erhardt 2005) and many studies were carried out to clarify the biological significance of genetic variants (Formaggioni et al. 1999, Kucerova et al. 2006). In this line of studies, for instance, B variants of beta-casein (Heck et al. 2009, Marziali \& Ng-KwaiHang 1986), kappa-casein (Caroli et al. 2004, Hallén et al.2008, Heck et al. 2009, Strzalkowska et al. 2002) and BLG (Daniela \& Vintila 2005, Hallén et al. 2008) were associated with an increase, whereas the E variant of kappa-casein (Hallén et al. 2008, Ikonen et al. 1997) was associated with a decrease in milk casein content and cheese yield/quality in various cattle breeds.

The purpose of the present study was to investigate the genetic diversity of beta-casein, kappa-casein and BLG proteins in four native Turkish cattle breeds (Turkish Grey, Eastern Anatolian Red, Anatolian Black and Southern Anatolian Red) and a non-native breed (Turkish Holstein) together with an independent sub-sample of the Holstein breed (Holstein Candidate Bulls). There is one previous DNA-based casein diversity study (Jann et al. 2004) covering only two of the native Turkish cattle breeds (Turkish Grey and Anatolian Black) and two milk-sample based studies on alpha s1 $_{1}$-casein, beta-casein, kappa-casein and BLG (Gurcan 2011, Oner \& Elmaci 2006) covering only Holstein cattle in Turkey. Results were expected to yield some realisations and proposals in relation to the milk properties of native cattle and breeding practices applied to native Turkish cattle breeds.

\section{Material and methods}

Cattle breeds, sampling

There were four native Turkish cattle breeds: Turkish Grey (TG), Eastern Anatolian Red (EAR), Anatolian Black (AB) and Southern Anatolian Red (SAR). For further information about the breeds see DAD-IS (Domestic Animal Diversity Information System, http://dad.fao.org/). Their collection sites coinciding with their native distributions of the samples employed in the present study are given in Figure 1.

The samples of Holstein cattle, which were first introduced to Turkey in 1958, were sampled from Thrace and are called Turkish Holstein $(\mathrm{TH})$ in the present study. The Holstein Candidate Bull (HCB) population was composed out of the first male offsprings born to the Turkish Holstein females distributed partly in Thrace and partly in the Northern Aegean region. These females were artificially inseminated by semen bought from Holland, the USA, Germany, Canada, Italy, Israel by the Cattle Breeders Association of Turkey in 1999 (Ozkan et al. 2009). Candidate Bulls were referred as population hereafter.

In the present study, the number of individuals studied per breed was composed as follows: 47 of TG, 41 of EAR, 42 of AB, 48 of SAR, 49 of TH and 27 of HCBs. In total, 254 individuals were studied. 

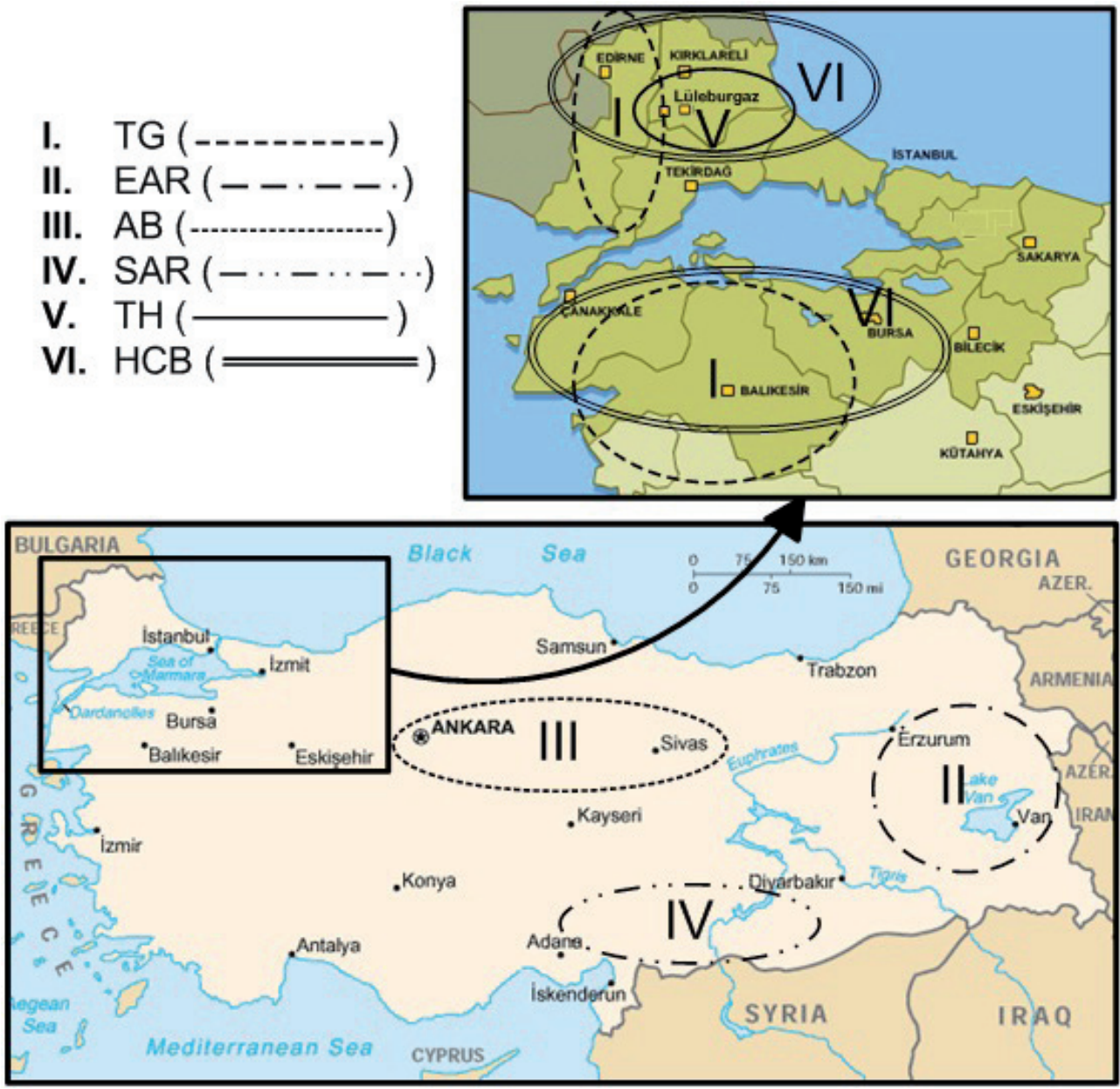

AB: Anatolian Black, EAR: Eastern Anatolian Red, HCB: Holstein Candidate Bulls, SAR: Southern Anatolian Red, TG: Turkish Grey, TH: Turkish Holstein

Figure 1

Native distribution and sampling sites of the breeds and population employed in the present study

\section{DNA extraction, genes and variants}

Total genomic DNA from the blood samples was isolated using the phenol-chloroformisoamylalcohol method (Sambrook et al. 1989). DNA samples were screened for beta-casein, kappa-casein and BLG milk protein gene variants. Employed beta-casein allelic variants were determined by single strand conformation polymorphisms (SSCP), amplification created restriction sites (ACRS) and sequencing methods according to Barroso et al. (1999a, b) and Lien et al. (1992). Sequencing of beta-casein gene was carried out by automatic DNA sequencing machine (ABI 310). Both kappa-casein and BLG allelic variants were investigated by the restriction fragment length polymorphism (RFLP) method according to Soria et al. (2003) and Medrano \& Aguilar-Cordova 1990, respectively. 


\section{Statistical analysis of data}

The calculation of the allele frequencies, observed heterozygosities and the presence of the Hardy-Weinberg equilibrium (by Fisher's exact test) were performed by the Arlequin ver 3.11 package program (Excoffier et al. 2006). The screening for the presence of withinpopulation inbreeding $\left(F_{i s}\right)$ based on the three loci (beta-casein, kappa-casein, BLG) and assessment of between breed/population diversity by pairwise $F_{\text {st }}$ values, according to the Weir \& Cockerham's (1984) approach, were done using the FSTAT v. 2.9.3.2 package program (Goudet 2002). The data were permutated for 1000 times in order to test the significance of the $F_{i s}$ and $F_{\text {st }}$ values. For the multiple tests in relation to the Hardy-Weinberg equilibrium, $F_{\text {is }}$ and $\mathrm{F}_{\mathrm{st}}$ the level of significance $(P<0.05)$ was adjusted with the Bonferroni correction.

\section{Results and discussion}

Observed allele frequencies, observed heterozygosities and the number of animals are presented in Table 1.

Table 1

The studied cattle breeds and population

\begin{tabular}{|c|c|c|c|c|c|c|c|}
\hline $\begin{array}{l}\text { Milk } \\
\text { Protein } \\
\text { Loci }\end{array}$ & $\begin{array}{c}\text { Breeds and } \\
\text { Population } \\
\text { Alleles }\end{array}$ & TG & EAR & $A B$ & SAR & $\mathrm{TH}$ & $\mathrm{HCB}$ \\
\hline \multirow{7}{*}{$\begin{array}{l}\text { Beta- } \\
\text { casein }\end{array}$} & $\mathrm{A} 1$ & 0.426 & 0.118 & 0.132 & 0.117 & 0.485 & 0.278 \\
\hline & $\mathrm{A} 2$ & 0.544 & 0.824 & 0.765 & 0.766 & 0.456 & 0.722 \\
\hline & A3 & 0.000 & 0.000 & 0.000 & 0.000 & 0.029 & 0.000 \\
\hline & B & 0.029 & 0.059 & 0.103 & 0.117 & 0.029 & 0.000 \\
\hline & A1-like $(A 1+B)$ & 0.455 & 0.177 & 0.235 & 0.234 & 0.514 & 0.278 \\
\hline & $\mathrm{H}_{\mathrm{o}}$ & 0.441 & 0.294 & 0.382 & 0.467 & 0.765 & 0.556 \\
\hline & $\mathrm{n}$ & 34 & 34 & 34 & 30 & 34 & 18 \\
\hline \multirow{5}{*}{$\begin{array}{l}\text { Kappa- } \\
\text { casein }\end{array}$} & A & 0.7021 & 0.6585 & 0.6548 & 0.6563 & 0.8061 & 0.7963 \\
\hline & B & 0.2979 & 0.3415 & 0.3452 & 0.3437 & 0.1939 & 0.1481 \\
\hline & $\mathrm{E}$ & 0.0000 & 0.0000 & 0.0000 & 0.0000 & 0.0000 & 0.0556 \\
\hline & $\mathrm{H}_{\mathrm{o}}$ & 0.383 & 0.293 & 0.452 & 0.438 & 0.306 & 0.296 \\
\hline & $\mathrm{n}$ & 47 & 41 & 42 & 48 & 49 & 27 \\
\hline \multirow{4}{*}{ BLG } & $A$ & 0.5213 & 0.2195 & 0.3929 & 0.1875 & 0.4694 & 0.5455 \\
\hline & B & 0.4787 & 0.7805 & 0.6071 & 0.8125 & 0.5306 & 0.4545 \\
\hline & $\mathrm{H}_{\mathrm{o}}$ & 0.489 & 0.390 & 0.310 & 0.292 & 0.449 & 0.546 \\
\hline & $\mathrm{n}$ & 47 & 41 & 42 & 48 & 49 & 22 \\
\hline
\end{tabular}

TG: Turkish Grey, EAR: Eastern Anatolian Red, AB: Anatolian Black, SAR: Southern Anatolian Red, TH: Turkish Holstein, HCB: Holstein Candidate Bulls), n: the number of animals, beta-casein, kappa-casein and BLG allele frequencies and observed heterozygosities. 
The probability of deviations from the Hardy-Weinberg expectations for beta-casein, kappacasein and BLG were calculated and no deviation from the Hardy-Weinberg equilibrium was observed in a total of 18 tests carried out for each gene and breed/population separately. In addition, the within-population inbreeding $\left(\mathrm{F}_{\text {is }}\right)$ values calculated on overall loci were not significant. These observations indicated that there is no significant substructuring or inbreeding within the breeds or population.

Unfortunately, for the Turkish native breeds data for phenotypes were not available. Therefore previously obtained general observations will be assumed to be the rule and some conclusions about the milk protein related properties of native breeds will be drawn.

The beta-casein B allele was found to be related with good cheese making property (Heck et al. 2009, Marziali \& Ng-Kwai-Hang 1986). The frequency of beta-casein B allele was generally high in Turkish native cattle breeds compared to TH and HCB, except in TG, whose value was identical to that of $\mathrm{TH}$. The highest beta-casein $\mathrm{B}$ allele frequency observed in Turkey in SAR (0.117) is comparable with those of the Guernsey breed (0.186) and the Brown Swedish breed in Germany (0.170) (Ehrmann et al. 1997).

The kappa-casein B allele was also found to be one of the most well-known alleles related to cheese quality (Ikonen et al. 1997, Medrano \& Aguilar-Cordova 1990, Strzalkowska et al. 2002). Indeed, breeds of countries famous for their cheeses (Italy, France, Germany, United Kingdom) seemed to exhibit relatively high frequencies of this allele (0.400-0.840) (Jann et al. 2004). The moderate kappa-casein B allele frequencies of Turkish native breeds (0.29790.3452) are close to those of Croatian (0.130-0.460), Polish (0.330) and Belgian (0.190-0.280) (Jann et al. 2004) breeds in Europe. Another point which is noteworthy is that the $E$ (»bad for cheese $\lll)$ allele of this locus is completely absent among the native Turkish breeds (except in HCB) and it is also absent in the Polish (Jann et al. 2004, Strzalkowska et al. 2002), Italian (Caroli et al. 2004, Jann et al. 2004), Belgian (Jann et al. 2004), French (Jann et al. 2004) and Croatian (Jann et al. 2004) breeds.

About the association between good cheese quality and high B allele frequency of BLG has previously been reported (Daniela \& Vintila 2005). In a recent study it was observed that yoghurt quality is also associated with the B allele of BLG (Hallén et al. 2009). The betalactoglobulin $B$ allele frequency ranges between 0.6071-0.8125 in EAR, AB and SAR breeds (see Table 1). These values are higher than most of the BLG B allele frequencies in European cattle populations; which range from 0.417 in Dutch Holstein-Friesian (Heck et al. 2009) to 0.720 in Finnish Ayrshire (lkonen 2000).

Both the B allele frequencies of kappa-casein and the BLG loci were higher than those of $\mathrm{TH}$ and $\mathrm{HCB}$. Yet, the TG frequency values were in between the three other Turkish native breeds (EAR, AB, SAR) and TH-HCB. The kappa-casein E allele was observed only in HCB.

Estimates of pairwise $F_{s t}$ values between each population pair and their significances, based on beta-casein, kappa-casein and BLG genes are presented in Table 2.

For the native Turkish cattle breeds, the dissimilarity of allele frequencies of milk protein genes (Table 2) is in accordance with their native distribution of east-west direction in Anatolia. Easternmost breeds, EAR and SAR, were genetically the most similar with respect to beta-casein, kappa-casein and BLG genes, AB joined to this pair and TG was the most distinct one among the native breeds (Table 2). Turkish Holstein and HCB are observed to be quite similar to each other as well as to TG (Table 2), which has been suggested to have a common 
origin with Balkan breeds (Pariset et al. 2010). Its difference from AB, EAR and SAR confirms this proposition (Table 2).

Table 2

Pairwise estimates of Fst values calculated by beta-casein, kappa-casein and BLG genes of the studied cattle breeds and population by using FSTAT software program.

\begin{tabular}{llccccc}
\hline $\begin{array}{l}\text { Breeds and } \\
\text { Population }\end{array}$ & TG & EAR & AB & SAR & TH & HCB \\
\hline TG & 0.0000 & & & & & \\
EAR & $0.1306^{* * *}$ & 0.0000 & & & & \\
AB & $0.0468^{\text {NS }}$ & $0.0149^{\text {NS }}$ & 0.0000 & & & \\
SAR & $0.1168^{* * * *}$ & $-0.0032^{\text {NS }}$ & $0.0186^{\text {NS }}$ & 0.0000 & & \\
TH & $0.0021^{\text {NS }}$ & $0.1793^{* * *}$ & $0.0961^{\text {NS }}$ & $0.1521^{* * *}$ & 0.0000 & \\
HCB & $0.0144^{\text {NS }}$ & $0.1182^{*}$ & $0.0338^{\text {NS }}$ & $0.1196^{* * *}$ & $0.0396^{\text {NS }}$ & 0.0000 \\
\hline
\end{tabular}

NS: Not significant, ${ }^{*} P<0.05,{ }^{* * *} P<0.001$, TG: Turkish Grey, EAR: Eastern Anatolian Red, AB: Anatolian Black, SAR: Southern Anatolian Red, TH: Turkish Holstein, HCB: Holstein Candidate Bulls

Allele frequencies observed previously by Oner \& Elmaci (2006) for Holstein and by Jann et al. (2004) for $A B$ and TG are quite similar with those of the present study indicating the reliability of the results.

Most (90\%) of the produced milk is bovine milk and it is consumed mostly as cheese (55.6\%) and yoghurt (19.6\%) in Turkey (Taşdan et al. 2008). Perhaps, especially due to the high frequency of the B allele of BLG and the absence of the E allele of kappa-casein, good quality cheese and yoghurt have been enjoyed over the ages in Anatolia.

The milk yield of Turkish native cattle is low (Taşdan et al. 2008). Therefore, in the 1970s in Turkey, an effort was made to modify the genetic make-up of the native breeds so that a higher milk yield would be obtained. For this purpose, native breeds started to be hybridised by economically important breeds: Holstein, Jersey, Brown Swiss and Simmental (Kumlu 2000) in Turkey. Yet, the danger of losing native breeds was realised (Kumlu 2000) and the practice of hybridisation between economically important and native Turkish breeds seems to have been stopped in the late 1980s (Kumlu 2000). Imported pure breeds with their high milk yield (for instance, Holstein) were established and without being recorded native breeds continued to be fertilised occasionally by Holstein Bulls in Turkey. Therefore, in the present study, samples of HCB were also examined to detect the possible impact of hybridisation with Holstein bulls, such as an introduction of "foreign « alleles to Turkish breeds. For instance, the E allele of the kappa-casein gene, which is present in HCB, could be introduced into Turkish native and Turkish Holstein breeds in the future.

As a conclusion, in this study, it is emphasized that while trying to increase the milk yield of native Turkish cattle breeds by fertilising them with Holstein bulls, it must be realised that we might change the quality of locally desired milk and dairy products.

\section{Acknowledgements}

We thank Prof. Dr. Ihsan Soysal for his help in the collection of the samples. This work was 
supported by grant TOVAG 104V137 from The Scientific and Technological Research Council of Turkey (TUBITAK).

\section{References}

Barroso A, Dunner S, Cañón J (1999a) Technical note: use of PCR-single-strand conformation polymorphism analysis for detection of bovine beta-casein variants A1, A2, A3, and B. J Anim Sci 77, 2629-2632

Barroso A, Dunner S, Cañón J (1999b) A multiplex PCR-SSCP test to genotype bovine $\beta$-casein alleles A1, A2, A3, B, and C. Anim Genet 30, 322-323

Caroli A, Chessa S, Bolla P, Budelli E, Gandini GC (2004) Genetic structure of milk protein polymorphisms and effects on milk production traits in a local dairy cattle. J Anim Breed Genet 121, 119-127

Ceriotti G, Marletta D, Caroli A, Erhardt G (2004) Milk protein loci polymorphism in taurine (Bos taurus) and zebu (Bos indicus) populations bred in hot climate. J Anim Breed Genet 121, 404-415

Daniela I, Vintila I (2005) Analysis of gene polymorphism at locus of $\mathrm{K}$-casein and $\beta$-lactoglobulin genes using multiplex PCR technique. Zootehnie şi Biotehnologii 38, 769-773

Ehrmann S, Bartenschlager H, Geldermann H (1997) Quantification of gene effects on single milk proteins in selected groups of dairy cows. J Anim Breed Genet 114, 121-132

Eigel WN, Butler JE, Ernstrom CA, Farrell Jr HM, Harwalkar VR, Jenness R, Whitney RMcL (1984) Nomenclature of Proteins of Cow's Milk: Fifth Revision. J Dairy Sci 67, 1599-1631

Excoffier L, Laval G, Schneider S (2006) Arlequin ver 3.01. An Integrated Software Package for Population Genetics Data Analysis. Computational and Molecular Population Genetics Lab (CMPG), Institute of Zoology, University of Berne, Switzerland

Formaggioni P, Summer A, Malacarne M, Mariani P (1999) Milk protein polymorphism: Detection and diffusion of the genetic variants in Bos Genus. Ann Fac Med Vet Univ Parma 19, 127-165

Goudet J (2002) FSTAT: A program to estimate and test gene diversities and fixation indices (Version 2.9.3.2), Department of Ecology \& Evolution, Biology Building, UNIL, Lausanne, Switzerland

Gurcan EK (2011) Association between milk protein polymorphism and milk production traits in Black and White dairy cattle in Turkey. Afr J Biotechnol 10, 1044-1048

Hallén E, Allmere T, Lundén A, Andrén A (2009) Effect of genetic polymorphism of milk proteins on rheology of acid-induced milk gels. Int Dairy J 19, 399-404

Hallén E, Wedholm A, Andrén A, Lundén A (2008) Effect of $\beta$-casein, $k$-casein and $\beta$-lactoglobulin genotypes on concentration of milk protein variants. J Anim Breed Genet 125, 119-129

Heck JML, Schennink A, van Valenberg HJF, Bovenhuis $\mathrm{H}$, Visker MHPW, van Arendonk JAM, van Hoojdonk ACM (2009) Effects of milk protein variants on the protein composition of bovine milk. J Dairy Sci 92, $1192-1202$

Ibeagha-Awemu EM, Erhardt G (2005) Genetic structure and differentiation of 12 African Bos indicus and Bos taurus cattle breeds, inferred from protein and microsatellite polymorphisms. J Anim Breed Genet 122, 12-20

Ikonen T, Ojala M, Syväoja EL (1997) Effects of composite casein and beta-lactoglobulin genotypes on renneting properties and composition of bovine milk by assuming an animal model. Agr Food Sci Finland 6, 283-294

Ikonen TL (2000) Possibilities of genetic improvement of milk coagulation properties of dairy cows. Academic Dissertation, University of Helsinki, Department of Animal Science Publications

Jann OC, Ibeagha-Awemu EM, Özbeyaz C, Zaragoza P, Williams JL, Ajmone-Marsan P, Lenstra JA, MoazamiGoudarzi K, Erhardt G (2004) Geographic distribution of haplotype diversity at the bovine casein locus. Genet Sel Evol 36, 243-257

Kučerová J, Lund MS, Sørensen P, Sahana G, Guldbrandtsen B, Nielsen VH, Thomsen B, Bendixen C (2006) Multitrait Quantitative Trait Loci Mapping for Milk Production Traits in Danish Holstein Cattle. J Dairy Sci $89,2245-2256$ 
Kumlu S (2000) [Rearing Cattle for Breeding and Butchery. Publications of Cattle Breeders Association of Turkey]. Turkey, 3 [in Turkish]

Lien S, Aleström P, Klungland H, Rogne S (1992) Detection of multiple $\beta$-casein (CASB) alleles by amplification created restriction sites (ACRS). Anim Genet 23, 333-338

Marziali AS, Ng-Kwai-Hang KF (1986) Effect of Milk Composition and Genetic Polymorphism on Cheese Composition: Minutes of the Executive Committee Meetings and Summary Reports of ADSA Committees and Representatives. J Dairy Sci 69, 2533-2542

Medrano JF, Aguilar-Cordova E (1990) Polymerase chain reaction amplification of bovine $\beta$-lactoglobulin genomic sequences and identification of genetic variants by RFLP analysis. Anim Biotechnol 1, 73-77

Oner Y, Elmaci C (2006) Milk protein polymorphisms in Holstein cattle. Int J Dairy Technol 59, 180-182

Ozkan E, Soysal MI, Ozder M, Koban E, Sahin O, Togan I (2009) Evaluation of parentage testing in the Turkish Holstein population based on 12 microsatellite loci. Livest Sci 124, 101-106

Pariset L, Mariotti M, Nardone A, Soysal MI, Ozkan E, Williams JL, Dunner S, Leveziel H, Maróti-Agóts A, Bodò I, Valentini A (2010) Relationships between Podolic cattle breeds assessed by single nucleotide polymorphisms (SNPs) genotyping. J Anim Breed Genet 127, 481-488

Rachagani S, Gupta ID, Gupta N, Gupta SC (2006) Genotyping of $\beta$-Lactoglobulin gene by PCR-RFLP in Sahiwal and Tharparkar cattle breeds. BMC Genet 7, 31-34

Sambrook J, Fritsch EF, Maniatis T (1989) Molecular Cloning: A Laboratory Manual. 2nd ed. Vol.3, New York: Cold Spring Harbor Laboratory, Cold Spring Harbor, USA

Soria LA, Iglesias GM, Huguet MJ, Mirande SL (2003) A PCR-RFLP Test to Detect Allelic Variants of the Bovine Kappa-Casein Gene. Anim Biotechnol 14, 1-5

Strzalkowska N, Krzyzewski J, Zwierzchowski L, Ryniewicz Z (2002) Effects of K-casein and $\beta$-lactoglobulin loci polymorphism, cows' age, stage of lactation and somatic cell count on daily milk yield and milk composition in Polish Black-and-White cattle. Anim Sci Pap Rep 20, 21-35

Taşdan K, İriboy S, Çeliker SA, Gül U, İçöz Y, Berkum SV (2008) Turkish Dairy Sector Analysis Report. Published in Sectoral Analysis: Dairy, Tomato, Cereals, Poult Agr Econ Res Inst (AERI)

Weir BS, Cockerham CC (1984) Estimating F-statistics for the analysis of population structure. Evolution 38, $1358-1370$ 